\title{
Efficacy of Naphthalene Balls in the Control of Rhinoceros Beetle Attacks in Coconut
}

\author{
S. SADAKATHULLA ${ }^{1}$ and T.K. RAMACHANDRAN ${ }^{2}$ \\ Coconut Research Station, Vappankulam - 614906 \\ Thanjavur District, India. \\ ${ }^{1}$ Associate Professor (Entomology) ${ }^{2}$ Professor and Head
}

\begin{abstract}
Different formulations of pesticides were applied to the base of inter-space of leaf sheath of the top-most three leaves in the crown of 42-month-old coconut seedlings to provide protection against attacks of rhinoceros beetle. Application of naphthalene balls (weighing 3.5 $\mathrm{g}$ each) at the rate of three balls per palm, one each to the base of three top-most leaf sheath, at 45 -day intervals was found give $100 \%$ protection against the pest attacks. The repellant action of naphthalene was significantly superior to that given by conventional insecticides such as $\mathrm{HCH} 10 \%$, Carbofuran or Phorate.
\end{abstract}

\section{INTRODUCTION}

The rhinoceros beetle, Oryctes rhinoceros L. (Scarabaeidae; Dynastinae) is one of the serious and important pests of coconut in all coconut growing countries. This beetle is widespread in all coconut growing areas of India. Besides coconut, it attacks and damages pineapple, sugarcane, palmyrah, date palm, African oil palm, tali-pot palm and royal palm. The adult beetle burrows and remains between leaf sheaths near the crown and cuts the leaf in the folded stage thereby causing permanent damage. When the attack is on the unopened spathe, the inflorescence becomes badly damaged and can cause 10 per cent annual reduction in yield. Frequent infestation results in reduction of leaves and stunting of trees. The damage can cause death in seedlings and young palms but adult palms can withstand infestations.

The practice of application of an insecticide/sand mixtures (1:1) containing insecticides such as chlordane $5 \%$ or aldrin $5 \%$ once in three months in the top-most three leaf axil interspaces, is yet effective. Although several workers (Abad et al., 1982; Jayaraman, 1985) have reported the efficiency of newer insecticides, Singh (1987) obtained significant control of rhinoceros beetle on coconut and oil palm replants when naphthalene balls were inserted at the rate of five balls/plant into the frond axils. Use of biocontrol agents such as the virus, Baculovirus oryctes and the fungus, Metarhizium anisopliae have also been effective in some countries (Bedford, 1986; Zelazny, 1983).

This paper reports the work done on comparing the efficacy of naphthalene balls with some insecticides in controlling rhinoceros beetle attacks. 


\section{MATERIALS AND METHODS}

The experiment was carried out at the Coconut Research Station of the Tamil Nadu Agricultural University, Veppankulam during 1988-89, in 3 1/2-year old coconut seedlings which were regularly attacked by rhinoceros beetle. The trial was laid out in RBD, replicated four times with seven treatments viz., (1) $\mathrm{HCH} 10 \%$ and fine sand (1:1), (2) Carbofuran $3 \mathrm{~g}$ and fine sand (1:2), (3) Phorate $10 \mathrm{~g}+$ fine sand (1:2), (4) Carbofuran $3 \mathrm{~g}$ in empty gelatine capsule@3 capsules per seedling, (5) Phorate $10 \mathrm{~g}$ in empty gelatine casules @ 3 capsules/seedling, (6) Naphthalene balls@3 balls per seedling and (7) Untreated control.

\section{Details of treatments}

The mixtures of $\mathrm{HCH} 10 \%+$ fine sand (1:1) and granular insecticide + fine sand $(1: 2)$ were prepared using $50 \mathrm{~g}$ and $10 \mathrm{~g}$ of the insecticide, respectively. In the case of capsules, the empty gelatine medical capsules (weighing $0.11 \mathrm{~g}$ each) were procured and filled with $1 \mathrm{~g}$ of the granular insecticide per capsule and tightly closed with its cap. Three such capsules/seedling were applied. The diameter and weight of the naphthalene balls were 1.5 $\mathrm{cm}$ and $3.5 \mathrm{~g}$ respectively and were used at the rate of 3 balls per seedling. The naphthalene balls were replaced at 45 -day intervals.

The treatments were applied to the base of the inter-space between the leaf sheaths of the three top-most leaves in the crown. Periodical observations at fortnightly intervals of the damage by the beetle $O$. rhinoceros were recorded and the cumulative protection computed.

\section{RESULTS AND DISCUSSION}

The degree of pest damage expressed as cumulative mean per cent protection, in the different treatments is given in Table 1.

Table 1- Effect of different formulations against rhinoceros beetle

\begin{tabular}{|c|c|}
\hline Treatment & $\begin{array}{l}{ }^{*} \text { Cumulative mean } \\
\text { per cent protection }\end{array}$ \\
\hline
\end{tabular}

$\begin{array}{lll}\text { HCH 10\% + Fine sand (1:1) } & 92.3 & (82.5) \\ \text { Carbofuran 3G. @10g + fine sand (1:2) } & 85.5 & (67.5) \\ \text { Phorate 10G. @10g + fine sand (1:2) } & 85.5 & (67.5) \\ \text { Carbofuran 3G. @ 1g in capsule @ } & & \\ \quad 3 \text { capsules/palm } & 85.5 & (67.5) \\ \text { Phorate 10G. @ 1g in capsule @ } & & \\ \quad 3 \text { capsules/palm } & 85.5 & (67.5) \\ \text { Naphthalene balls @ 3 Noș./palm } & 100.0 & (90.0) \\ \text { Untreated (control) } & 6.7 & (15.0) \\ \quad \text { LSD (P=0.05) } & 18.8 & \end{array}$

Figures in parenthesis are transformed values. $\quad{ }^{*}$ mean of four replications. 
Application of naphthalene balls at the rate of three balls per seedling to the base of leaf axils and repeated at 45-day interval was found to be the best treatment and was significantly superior $(p<0.05)$. This finding is in agreement with that of Singh (1987) wherein he used five naphthalene balls per palm. $\mathrm{HCH} 10 \%+$ fine sand (1:1) was the next best and all other treatments had similar effect.

This experiment clearly shows the efficacy of naphthalene balls in controlling rhinoceros beetle attacks. Application of naphthalene balls is quite easy and economical, compared to insecticide mixtures and affords effective protection against the rhinoceros beetle. The growers can apply naphthalene balls easily, even in the homegardens.

\section{REFERENCES}

Abad, R G., Gallego, C E and Aterrado, E D (1982) Evaluation of leaf axil placement of six granular insecticides against rhinoceros beetle (Oryctes rhinoceros L.) in young coconut palms. Philip. J. Coc. Studies.7(1-2): 23-27.

Bedford, G (1986) Biological control of thinoceros beetle Agriculture, Ecosystem and Environment 15(2/3): 141-147.

Jayaraman, V (1985) Study on repellant action of phorate against rhinoceros beetle, Oryctes rhinoceros Lin. In Behavioural and Physiological Approaches in pest management". (Eds. A. Regupathy \& S Jayaraj). Tamilnadu Agricultural University, Coimbatore; pp 116-119.

Singh G, (1987) Naphthalene balls for the protection of coconut and oil palms against Oryctes rhinoceros. Planter 63: 286-292.

Zelazny, B (1983) Oryctes rhinoceros damage on coconut palms in Maldives FAO Plant Prot. Bull. 31(3): 119-120. 